\title{
Histone H2A Significantly Enhances In Vitro DNA Transfection
}

\author{
Danuta Balicki and Ernest Beutler \\ The Scripps Research Institute, Department of Molecular and \\ Experimental Medicine, La Jolla, California, U.S.A.
}

\begin{abstract}
Background: Gene transfer is a potential treatment modality of genetic disease. Efficient, practical methods of DNA transfection are currently under investigation.

Materials and Methods: A $\beta$-galactosidase reporter plasmid interacted electrostatically with histones, poly-L-Lys, poly-L-Arg, and a combination of poly-L-Lys and poly-L-Arg. This complex was then used to transfect COS- 7 cells. $\beta$-galactosidase activity was quantified and used to compare the efficiency of gene transfection in vitro. A comparison was also made of DNA transfection with the most active histone subclass, i.e., histone $\mathrm{H} 2 \mathrm{~A}$, in the absence and presence of an anionic liposome.
\end{abstract}

Results: There was a marked increase in DNA

transfection in the presence of histone $\mathrm{H} 2 \mathrm{~A}$ when compared with the control, whereas each of the other histones and polycations showed little, if any, effect. The extent of activation depends strongly on the DNA/histone ratio and is also a function of the molarity of the final Tris-acetate, $\mathrm{pH} 8$, solution. The anionic liposomes used demonstrated an inhibitory effect.

Conclusions: Histone H2A significantly enhances in vitro DNA transfection whereas other histones and anionic liposomes do not. A study of the difference between histone $\mathrm{H} 2 \mathrm{~A}$ and other histone subclasses may serve to clarify some of the mechanisms and the essential components of efficient gene delivery.

\section{INTRODUCTION}

The goal of gene transfer therapy is to deliver the gene or cDNA of interest to a target cell and for it to be transcribed and translated in that cell. Because viruses have evolved to perform this function as efficiently as possible, the main focus of this type of therapeutic effort has been the use of modified viral vectors. However, the limitations of viral vectors have included potential pathogenicity and antigenicity, and attention has therefore turned to the promise associated with nonviral means of delivering genes. Cationic liposomes have been used successfully for both in vitro and in vivo gene transfer (1-3). However, some cell types, particularly macrophages, have proven very difficult to transfect. Yet, for the treatment of some diseases, such as Gaucher disease, targeting these cells would be an essen-

Address correspondence and reprint requests to: Dr. Ernest Beutler, The Scripps Research Institute, 10550 North Torrey Pines Road, La Jolla, CA 92037, U.S.A. Phone: 619-

784-8040; Fax: 619-784-2083; E-mail: beutler@scripps.edu tial part of a gene therapy therapeutic strategy. In the course of attempting to target macrophages with DNA/liposome complexes it occurred to us that liposomes containing the negatively charged lipid phosphatidylserine (PS) might target macrophages because of the existence of a PS receptor on macrophages (4-7). However, such negatively charged liposomes were almost entirely ineffective in transfecting macrophages. We therefore attempted to enhance in vitro gene transfection of a reporter gene in the presence of anionic liposomes and histones. We reasoned that complexing DNA with histones might improve transfection by two mechanisms: (1) unneutralized positive charges on the histone would be bound electrostatically both by the negatively charged phosphate backbone of DNA and the anionic liposome; and (2) nuclear targeting signals in histones might improve trafficking of the DNA to the nucleus where it could be transcribed. We now report an apparently unique property of histone $\mathrm{H} 2 \mathrm{~A}$ in enhancing DNA transfection. 


\section{MATERIALS AND METHODS}

\section{DNA, Histones, and Polycations}

The plasmid DNA used throughout these experiments was pCMV $\beta$ (Clontech, Palo Alto, CA). $\mathrm{pCMV} \beta$ is a $\beta$-galactosidase reporter plasmid under the control of a CMV promoter. Plasmid DNA was prepared using a Qiagen (Chatsworth, CA) Plasmid Giga kit and Endofree Plasmid Buffer Set. Dilutions of plasmid DNA were subjected to electrophoresis along with dilutions of lambda DNA-HindIII Digest (New England Biolabs, Beverly, MA) on a $0.9 \%$ SeaKemGTG (Rockland, ME) agarose gel in $1 / 2 \times$ Tris-phosphate (TPE) buffer. Circularized plasmid DNA was then quantified using Stratagene's Eagle Eye II Still Video System (La Jolla, CA). Histone H1, histone $\mathrm{H} 2 \mathrm{~A}$, histone $\mathrm{H} 2 \mathrm{~B}$, histone $\mathrm{H} 3$, and histone $\mathrm{H} 4$ were purchased from Boehringer Mannheim (Indianapolis, IN). Poly-L-Lys hydrobromide $(\mathrm{MW}=3970)$, and poly-L-Arg hydrochloride $(M W=12,100)$ were purchased from Sigma (St. Louis, MO).

\section{Liposomes}

The anionic liposomes contained phosphatidylcholine and phosphatidylserine (PC/PS) (5-7). These lipids, derived from brain, were purchased from Avanti Polar Lipids (Alabaster, AL) as stock solutions in chloroform. They were mixed in a $7: 3$ molar ratio in a round bottom flask. The chloroform was evaporated under argon (Parsons Airgas, San Diego, CA). Residual chloroform was eliminated under vacuum in a lyophilizer (Virtis Freezemobile 6, Gardiner, CA) over a 2 -hr period. Sufficient sterile, double-distilled water was then introduced into the flask for a final lipid concentration of $2 \mathrm{mg} / \mathrm{ml}$. The contents of the flask were vortexed until a homogeneous solution formed. The liposomes were then stored under argon at $4^{\circ} \mathrm{C}$ in sterile $15-\mathrm{ml}$ polypropylene centrifuge tubes (Corning Inc., Corning, New York).

\section{Transfection Assay}

The transfection assay is based on an in vitro assay previously described by J. H. Felgner et al. (8) with the following modifications: COS-7 (African green monkey SV40-transformed kidney cells, American Type Culture Collection, Rockville, MD) were maintained in Dulbecco's modified Eagle's medium (Biowhittaker, Walkersville, $\mathrm{MD})$ supplemented with $10 \%$ heat inactivated fetal bovine serum (FBS) (Gemini Bio-products Inc., Calabras, CA), 4 mM L-glutamine (Gemini Bio-products Inc.), and $100 \mathrm{U}$ penicillin-100 $\mu \mathrm{g}$ streptomycin/ml medium (Gemini Bio-products Inc.). The cells were harvested with $0.05 \%$ Trypsin- $0.53 \mathrm{mM}$ EDTA-4Na (Life Technologies, Gaithersburg, MD), pelleted, resuspended in their usual culture medium, diluted in $0.85 \% \mathrm{NaCl}$ (Sigma), and counted in a Coulter Zl apparatus (Coulter Corporation, Miami, FL). COS-7 cells were plated in 96-well, flat-bottom, tissue culture-treated polystyrene plates (Corning Inc.) at a density of $4 \times 10^{4}$ cells per well and grown overnight in a humidified incubator at $37^{\circ} \mathrm{C}$ in the presence of $4 \% \mathrm{CO}_{2}$. Culture medium was aspirated from the overnight cultures of COS-7 cells, and the cells were overlaid with $75 \mu \mathrm{l} /$ well of the binary DNAhistone H2A complex, the ternary DNA-histone H2A-PC/PS anionic liposome complex, or the corresponding controls. Four hours after transfection, $37.5 \mu \mathrm{l}$ of Opti-MEM 1 (Life Technologies) containing $30 \%$ heat inactivated FBS (Gemini Bio-products Inc.) was added to each well. Twenty-four hours post-transfection, $75 \mu \mathrm{l}$ of Opti-MEM 1 containing $10 \%$ heat inactivated FBS (Gemini Bio-products Inc.) was added to each well. Forty-eight hours post-transfection, all of the medium in each well was removed. Fifty microliters of lysis buffer $(0.1 \%$ Triton X$100,250 \mathrm{mM}$ Tris, $\mathrm{pH} 8.0$ ) was added to each well. The plates were then frozen at $-70^{\circ} \mathrm{C}$ and thawed once. Fifty microliters of phosphate-buffered saline (PBS), $\mathrm{pH}$ 7.4, was added to each well, except for the last column. The last column was reserved for a $\beta$-galactosidase standard curve. In this column, $50 \mu \mathrm{l}$ of two-fold serial dilutions of $\beta$-galactosidase grade VIII from $E$. coli (Sigma) were made in PBS, pH 7.4. Finally, $75 \mu \mathrm{l}$ of $1.0 \mathrm{mg} / \mathrm{ml}$ chlorophenol red galactopyranoside (CPRG; Boehringer Mannheim) in $\beta$-galactosidase buffer $(60 \mathrm{mM}$ sodium dibasic phosphate, $\mathrm{pH}$ 8.0, $1 \mathrm{mM}$ magnesium sulfate, $10 \mathrm{mM}$ $\mathrm{KCl}, 50 \mathrm{mM} \beta$-mercaptoethanol) was added in each well. In the presence of $\beta$-galactosidase, $D$-galactose is released from CPRG, yielding chlorophenol red; the red reaction product was used to quantitate the amount of $\beta$-galactosidase produced. The reaction was stopped by introducing $75 \mu \mathrm{l}$ of $20 \%$ Tris base ( $\mathrm{pH} 11$ ) into each well after sufficient time had elapsed for the standard curve to be in the appropriate linear range, usually between 5 and $15 \mathrm{~min}$ after the introduction of CPRG. The plates were read in a Thermomax plate reader (Molecular Devices, Sunnyvale, CA) 
at $575 \mathrm{~nm}$. The optical density values obtained in test wells were then compared with those in the column containing the $\beta$-galactosidase standard and the result was expressed as the quantity of $\beta$-galactosidase produced per well. All assays were performed in triplicate.

\section{RESULTS}

\section{Effect of Histones and Cationic} Polyelectrolytes on Transfection Efficiency

Complexes of the five different subclasses of histones with DNA, poly-L-Lys, poly-L-Arg, and a combination of poly-L-Lys and poly-L-Arg were assayed for transfection efficiency. Plasmid DNA was diluted to a final concentration of $80 \mu \mathrm{g} / \mathrm{ml}$ in $240 \mathrm{mM}$ Tris-acetate, $\mathrm{pH} 8$, made up in sterile endotoxin-free water (Biowhittaker's LAL Reagent Water, Walkersville, MD). Histones were diluted in sterile endotoxin-free water to a final concentration of $1 \mathrm{mg} / \mathrm{ml}$. The polycations polyL-Lys and poly-L-Arg were diluted in sterile endotoxin-free water to a final concentration of 147 and $150 \mu \mathrm{g} / \mathrm{ml}$, respectively, and used in this assay in an equivalent charge ratio $(9,10)$ as in histones. Twenty microliters each of plasmid DNA, histones, or polycations at the above concentrations was combined for $30 \mathrm{~min}$ at room temperature in polypropylene tubes (Corning Inc.) and then added to $40 \mu \mathrm{l}$ of Opti-MEM 1 (Life Technologies) resulting in a final Tris-acetate concentration of $60 \mathrm{mM}$. Control experiments were performed by replacing the histone/ polycation component of the above experiments with sterile endotoxin-free water in the presence and absence of DNA; when DNA was omitted, it was replaced with a corresponding volume, $\mathrm{pH}$, and molarity of Tris-acetate.

The average of triplicate samples and the standard error for each combination are presented in Figure 1. DNA transfection was markedly increased, to more than $2 \times 10^{5}$ times the background level, in the presence of histone $\mathrm{H} 2 \mathrm{~A}$ as compared with the control, whereas each of the other histones and polycations studied showed little, if any, effect.

\section{$\beta$-galactosidase Expression in the Presence of Histone H2A with and without PC/PS Anionic Liposomes}

To compare the effect of histone $\mathrm{H} 2 \mathrm{~A}$ on DNA transfection in the absence and presence of

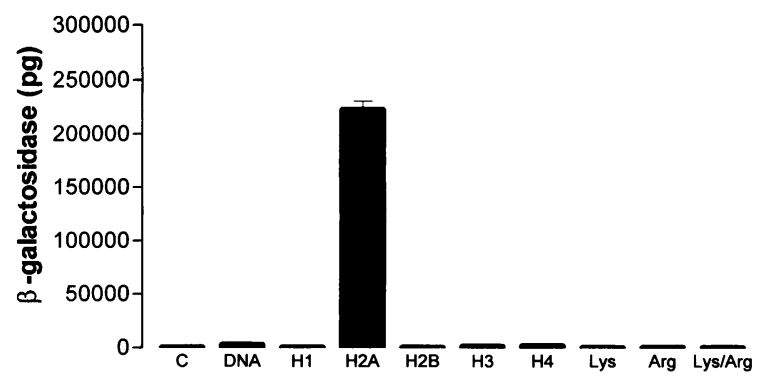

FIG. 1. $\beta$-galactosidase formed (pg) by COS-7 cells transfected with pCMV $\beta$ and control medium (C), DNA alone (DNA), and after complexing with the five different histone subclasses (H1, H2A, H2B, H3, H4), poly-L-Lys (Lys), poly-L-Arg (Arg), and a combination of poly-L-Lys and poly-L-Arg (Lys/Arg). Standard errors of the means of triplicates are shown.

PC/PS anionic liposomes, plasmid DNA was diluted to a final concentration of $80 \mu \mathrm{g} / \mathrm{ml}$ in 20 $\mathrm{mM}$ Tris-acetate, $\mathrm{pH} 8$, and combined with an equal volume of histone $\mathrm{H} 2 \mathrm{~A}$ at a concentration of $1 \mathrm{mg} / \mathrm{ml}$ in sterile endotoxin-free water (Biowhittaker's LAL Reagent Water). The mixture, a total volume of $35 \mu \mathrm{l}$, was allowed to stand for $30 \mathrm{~min}$ at room temperature. Then $35 \mu \mathrm{l}$ of Opti-MEM 1 was added to the binary complex. PC/PS liposomes at an initial concentration of 2 $\mathrm{mg} / \mathrm{ml}$ in $20 \mathrm{mM}$ Tris-acetate, $\mathrm{pH} 8$, were diluted in Opti-MEM 1 to a final concentration of 0.05 $\mathrm{mg} / \mathrm{ml}$ and $0.04 \mathrm{mg} / \mathrm{ml}$. Sixty microliters of the DNA-histone mixture was then added to $30 \mu \mathrm{l}$ of the liposomes for $30 \mathrm{~min}$ at room temperature. Control experiments were done in an identical fashion except that sterile water was substituted for liposomes.

Two different liposome concentrations were used. Figure 2 shows that DNA transfection was very efficient in the presence of histone $\mathrm{H} 2 \mathrm{~A}$, but was diminished when anionic liposomes were added. In the absence of histone the liposomes alone were unable to produce any significant transfection of the COS-7 cells.

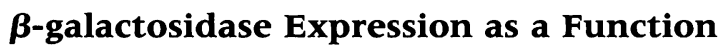 of Tris-Acetate Molarity}

The effect of molarity of the solution in which the binary complex is formed was studied by varying the final Tris-acetate, $\mathrm{pH} 8$, concentrations of the DNA-histone binary complex as follows: 1, 5, 15, 30, 60, and $100 \mathrm{mM}$ (Fig. 3). The binary complexes studied were DNA-histone 


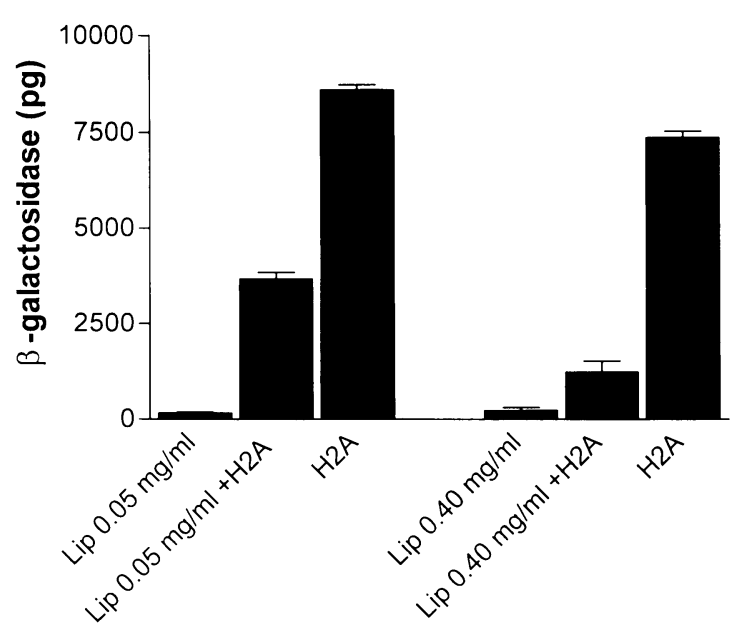

FIG. 2. $\beta$-galactosidase formed (pg) by COS-7 cells transfected with pCMV $\beta$ with histone $\mathrm{H} 2 \mathrm{~A}$ alone (H2A) in the presence of anionic liposomes with histone (Lip $0.05 \mathrm{mg} / \mathrm{ml}+\mathrm{H2A}$, Lip $0.40 \mathrm{mg} / \mathrm{ml}+\mathrm{H2A}$ ) and in the presence of liposomes alone (Lip). Because dilution with the liposomes produce a slight change in ionic strength, separate $\mathrm{H} 2 \mathrm{~A}$ controls are shown. Standard errors of the means of triplicates are shown.

$\mathrm{H} 2 \mathrm{~A}$ and DNA-histone $\mathrm{Hl}$. In the controls the histone component was replaced with endotoxin-free water. In this system, $\beta$-galactosidase activity in the histone $\mathrm{H} 2 \mathrm{~A}$ experiment peaked at $60 \mathrm{mM}$ Tris-acetate, $\mathrm{pH}$ 8. $\beta$-galactosidase activity was negligible with histone $\mathrm{Hl}$.

\section{$\beta$-galactosidase Expression as a Function of the DNA/Histone H2A Ratio}

The effect of the DNA/histone $\mathrm{H} 2 \mathrm{~A}$ ratio was analyzed by varying the DNA concentration throughout the range of 20,40, 80, and 160 $\mu \mathrm{g} / \mathrm{ml}$ (Table 1). Each of these DNA concentrations was then combined with an equal volume of histone $\mathrm{H} 2 \mathrm{~A}$ at $0.03125,0.0625,0.125,0.25$, $0.5,1,2$, and $4 \mathrm{mg} / \mathrm{ml}$, respectively, in triplicate for $30 \mathrm{~min}$ at room temperature in polypropylene tubes. The volume of the resulting binary complex was $40 \mu \mathrm{l}$ and this volume was combined with $40 \mu$ l of Opti-MEM 1, yielding a final Tris-acetate, $\mathrm{pH} 8$, concentration of $60 \mathrm{mM}$. As shown in Table 1, only 3 of the 32 combinations tested resulted in significant $\beta$-galactosidase activity; these were the combinations of histone $\mathrm{H} 2 \mathrm{~A}$ at $1 \mathrm{mg} / \mathrm{ml}(71.6 \mu \mathrm{M})$ with DNA at 80 $\mu \mathrm{g} / \mathrm{ml}(0.0168 \mu \mathrm{M})$, and histone $\mathrm{H} 2 \mathrm{~A}$ at 0.5 $\mathrm{mg} / \mathrm{ml}(35.8 \mu \mathrm{M})$ with DNA at $40 \mu \mathrm{g} / \mathrm{ml}$

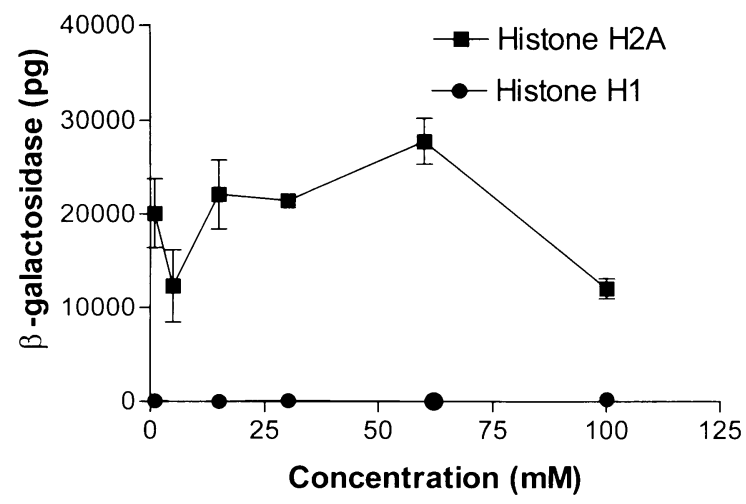

FIG. 3. $\beta$-galactosidase formed (pg) by COS-7 cells transfected with pCMV $\beta$ and histone $\mathrm{Hl}$ $(\Theta)$ and $\mathrm{H} 2 \mathrm{~A}(\square)$ as a function of the molarity of the Tris-acetate, pH 8, buffer in which the binary histone-DNA complex was made. Standard errors of the means of triplicates are shown.

$(0.00084 \mu \mathrm{M})$ and $20 \mu \mathrm{g} / \mathrm{ml}(0.0042 \mu \mathrm{M})$, respectively. Peak activity was observed using the combination of histone $\mathrm{H} 2 \mathrm{~A}$ at $0.5 \mathrm{mg} / \mathrm{ml}(35.8$ $\mu \mathrm{M})$ and DNA at $40 \mu \mathrm{g} / \mathrm{ml}(0.0084 \mu \mathrm{M})$, a molar ratio of about 4000:1 for histone to DNA.

\section{DISCUSSION}

In the transfection assay that we have described, DNA transfection is significantly enhanced in the presence of histone $\mathrm{H} 2 \mathrm{~A}$, and this activity is partially inhibited in the presence of anionic liposomes. Transfection efficiency in the presence of histone $\mathrm{H} 2 \mathrm{~A}$ increases as a function of the molarity of the medium in which the binary complex is formed. Significantly, neither histone $\mathrm{H} 1$, $\mathrm{H} 2 \mathrm{~B}, \mathrm{H} 3, \mathrm{H} 4$, poly-L-lysine, poly-L-arginine, nor a combination of these two polycations at an equivalent charge ratio showed any significant effect on DNA transfection. This shows clearly that our results cannot be attributed solely to the presence of basic amino acids but to a unique property of the histone $\mathrm{H} 2 \mathrm{~A}$ molecule.

Little is known of the effect of histones on the transfection of cells. Histone $\mathrm{H} 2 \mathrm{~A}$ has been reported to increase the efficiency of retroviral infection, possibly as a result of the basic amino acid transport capacity of the cell surface receptor for ecotropic murine retroviruses (11). A few very recent publications studying the effect of histones on gene expression in the presence of liposomes and polyamines have appeared (12- 
TABLE 1. $\beta$-galactosidase activity $(\mu \mathrm{g})$ of COS-7 cells transfected with pCMV $\beta(20,40,80$, and $160 \mu \mathrm{g} /$ $\mathrm{ml})$ and histone $\mathrm{H2A}(0.03125,0.0625,0.125,0.25,0.5,1,2$, and $4 \mathrm{mg} / \mathrm{ml})$

\begin{tabular}{|c|c|c|c|c|c|}
\hline $\begin{array}{l}\text { Histone H2A } \\
\mathrm{mg} / \mathrm{ml}(\boldsymbol{\mu M})\end{array}$ & $\begin{array}{c}\text { DNA } 160 \mu \mathrm{g} / \mathrm{ml} \\
(0.0337 \mu \mathrm{M})\end{array}$ & $\begin{array}{c}\text { DNA } 80 \mu \mathrm{g} / \mathrm{ml} \\
(0.0168 \mu \mathrm{M})\end{array}$ & $\begin{array}{c}\text { DNA 40 } \mu \mathrm{g} / \mathrm{ml} \\
(0.0084 \mu \mathrm{M})\end{array}$ & $\begin{array}{l}\text { DNA } 20 \mu \mathrm{g} / \mathrm{ml} \\
(0.0042 \mu \mathrm{M})\end{array}$ & $\mathbf{0}$ \\
\hline $4.0(286.5)$ & $7.80 \pm-0.60$ & $4.94 \pm 0.35$ & $2.69 \pm 2.01$ & $0.55 \pm 0.028$ & \\
\hline $2.0(143.3)$ & $9.54 \pm 1.17$ & $7.92 \pm 3.38$ & $0.19 \pm 0.14$ & $0.074 \pm 0.073$ & \\
\hline $1.0(71.6)$ & $0.93 \pm 0.17$ & $158.23 \pm 18.65$ & $4.70 \pm 2.80$ & $-0.23 \pm 0.022$ & \\
\hline $0.5(35.8)$ & $2.03 \pm 0.45$ & $0.93 \pm 0.10$ & $195.18 \pm 8.77$ & $37.50 \pm 1.87$ & \\
\hline $0.25(17.9)$ & $0.37 \pm 0.10$ & $0.65 \pm 0.20$ & $-0.56 \pm 0.17$ & $10.80 \pm 3.13$ & \\
\hline $0.125(8.95)$ & $0.73 \pm 0.23$ & $0.88 \pm 0.50$ & $-0.62 \pm 0.06$ & $1.22 \pm 1.37$ & \\
\hline $0.0625(4.48)$ & $0.65 \pm 0.22$ & $0.98 \pm 0.38$ & $-0.93 \pm 0.23$ & $-0.59 \pm 0.27$ & \\
\hline $0.03125(2.24)$ & $1.04 \pm 0.47$ & $0.81 \pm 0.18$ & $-1.01 \pm 0.23$ & $-1.18 \pm 0.12$ & \\
\hline 0 & $-0.11 \pm 0$ & $0.42 \pm 0.50$ & $-0.09 \pm 0.06$ & $0.65 \pm 0.17$ & $0.003 \pm 2$ \\
\hline
\end{tabular}

The combinations giving the most efficient transfection are shown in bold. The values shown are the means of triplicates \pm 1 S.E.

14). The postulated mechanism by which histone $\mathrm{H} 1$ increases gene transfection is through DNA condensation. In these studies, histone $\mathrm{Hl}$ was considered to be the subclass of histones that mediates efficient gene transfer. In our assay system histone $\mathrm{Hl}$ manifested negligible activity compared with histone H2A. The difference in our results may be accounted for by the composition of our polyplexes (cationic polymer/nucleic acid complex) (15), histone source, and the manner in which the components of our assay were diluted, i.e., Tris-acetate buffer vs. OptiMEM 1. We have also tried to limit the endotoxin content in our system as it is known to diminish the efficiency of DNA transfection (16), and all analyses were performed in the absence of chloroquine.

The mechanism of the striking effect of histone $\mathrm{H} 2 \mathrm{~A}$ on transfection efficiency is not yet clear. It could be that this histone increases the number of plasmids that enter the cell or that it improves the efficiency with which the plasmids are expressed, either by facilitating their entry into the nucleus or by increasing the efficiency with which they are transcribed. The extraordinary difference between the effect of histone $\mathrm{H} 2 \mathrm{~A}$ and the other histones tested is of special interest and may lead to further insights into the mechanism of action. It may be that there are amino acid sequences in histone $\mathrm{H} 2 \mathrm{~A}$, not represented in other histones, that are important for efficient transfection. It may also be that the extent or location of acetylated residues in this histone are of special importance, since a correlation between histone acetylation and transcriptionally active chromatin is known to exist $(17,18)$.

\section{ACKNOWLEDGMENTS}

Drs. P. L. Felgner and O. Zelphati (Vical, Inc., San Diego, CA) are gratefully acknowledged for numerous helpful discussions. We thank Dr. Timo L. M. ten Hagen (Rotterdam, The Netherlands) for his gift of PC/PS liposomes that were used in preliminary experiments. Susan Sackmann is gratefully acknowledged for skillful technical assistance. D. Balicki is a recipient of The Medical Research Council of Canada's Clinician-Scientist Award. This is manuscript 11055-MEM from The Scripps Research Institute. This work was supported by National Institutes of Health grant RR00833 and the Stein Endowment Fund.

\section{REFERENCES}

1. Felgner PL. (1997) Nonviral strategies for gene therapy. Sci. Am. 276: 102-106.

2. Zhu N, Liggitt D, Liu Y, Debs R. (1993) Systemic gene expression after intravenous DNA delivery into adult mice. Science 261: 209-211. 
3. Debs R, Pian $M$, Gaensler $K$, Clements J, Friend DS, Dobbs L. (1992) Prolonged transgene expression in rodent lung cells. Am. $J$. Respir. Cell Mol. Biol. 7: 406-413.

4. Greenspan P. (1990) Phosphatidylserinemediated delivery of cholesterol to macrophages: A novel experimental method for the generation of foam cells. Biochim. Biophys. Acta 1: 94-96.

5. Fidler IJ, Raz A, Fogler WE, Kirsh R, Bugelski P, Poste G. (1980) Design of liposomes to improve delivery of macrophage-augmenting agents to alveolar macrophages. Cancer Res. 40: 4460-4466.

6. Campbell MJ. (1995) Lipofection reagents prepared by a simple ethanol injection technique. BioTechniques 18: 1027-1032.

7. Lee KD, Nir S, Papahadjopoulos D. (1993) Quantitative analysis of liposome-cell interactions in vitro: Rate constants of binding and endocytosis with suspension and adherent J774 cells and human monocytes. Biochemistry 3: 889-899.

8. Felgner JH, Kumar R, Sridhar $\mathrm{CN}$, et al. (1994) Enhanced gene delivery and mechanism studies with a novel series of cationic lipid formulations. J. Biol. Chem. 269: 25502561.

9. Wolfert MA, Schacht EH, Toncheva V, Ulbrich K, Nazarova O, Seymour LW. (1996) Characterization of vectors for gene therapy formed by self-assembly of DNA with synthetic block co-polymers. Hum. Gene Ther. 7: 2123-2133.

10. Wolfert MA, Seymour LW. (1996) Atomic force microscopic analysis of the influence of the molecular weight of poly (L)lysine on the size of polyelectrolyte complexes formed with DNA. Gene Ther. 3: 269-273.

11. Singh D, Rigby PWJ. (1996) The use of histone as a facilitator to improve the efficiency of retroviral gene transfer. Nucl. Acids Res. 24: 3113-3114.

12. Fritz JD, Herweijer H, Zhang G, Wolff JA. (1996) Gene transfer into mammalian cells using histone-condensed plasmid DNA. Hum. Gene Ther. 7: 1395-1404.

13. Hagstrom JE, Sebestyen MG, Budker V, Ludtke JJ, Fritz JD, Wolff JA. (1996) Complexes of non-cationic liposomes and histone Hl mediate efficient transfection of DNA without encapsulation. Biochim. Biophys. Acta 1284: 47-55.

14. Budker V, Hagstrom JE, Lapina O, Eifrig D, Fritz J, Wolff JA. (1997) Protein/amphipathic polyamine complexes enable highly efficient transfection with minimal toxicity. BioTechniques 23: 139-147.

15. Felgner PL, Barenholz Y, Behr JP, et al. (1997) Nomenclature for synthetic gene delivery systems. Hum. Gene Ther. 8: 511-512.

16. Wicks IP, Howell ML, Hancock T, Kohsaka H, Olee T, Carson DA. (1995) Bacterial lipopolysaccharide copurifies with plasmid DNA: Implication for animal models and human gene therapy. Hum. Gene Ther. 6: 317-323.

17. Gavazzo P, Vergani L, Mascetti GC, Nicolini C. (1997) Effects of histone acetylation on chromatin structure. J. Cell. Biochem. 64: 466-475.

18. Pazin MJ, Kadonaga JT. (1997) What's up and down with histone deacetylation and transcription. Cell 89: 325-328.

Communicated by E. Beutler. Accepted September 24, 1997. 